\title{
SISTEM INFORMASI ADMINISTRASI SURAT MENYURAT KANTOR WILAYAH KEMENTERIAN AGAMA PROVINSI RIAU
}

\author{
Nurul Ikhsan'), Siti Ramadhani' ${ }^{2}$ \\ ${ }^{1}$ Fakultas Sains dan Teknologi, UIN Sultan Syarif Kasim, Riau, Indonesia. \\ Email:nrlikhsan20@gmail.com \\ ${ }^{2}$ Fakultas Sains dan Teknologi, UIN Sultan Syarif Kasim, Riau, Indonesia. \\ Email: siti.ramadhani@uin-suska.ac.id
}

\begin{abstract}
The Regional Office of the Ministry of Religion of Riau Province is the Ministry in charge of religious affairs. The Regional Office of the Ministry of Religion of Riau Province has an important part in public service information, namely the One-Stop Integrated Senvice Center is a section that collects all information relating to activities in the field of letter information at the Regional Office of the Ministry of Religion of the Province of Riau. PTSP Employees will collectandprocess dataonincoming and outgoing documents making correspondence still using conventional methods. Based on existing considerations, an information system will be built that can help PTSP employees in the Regional Office of the Ministry of Religion in Riau Province. Based on the blackbox test results the system is nunning well and as expected. Based on the User Acceptance Test (UAT) that has been carried out by the system user at the Regional Office of the Ministry of Religion in Riau Province, the overall system is easy to understand and in accordance with what is expected.
\end{abstract}

Keywords: Regional Office of Ministry of Religion of Riau Province, Administrative Information System of Correspondence

Abstrak

Kantor Wilayah Kementerian Agama Provinsi Riau adalah Kementerian yang membidangi urusan keagamaan. Kantor Wilayah Kementerian Agama Provinsi Riau memiliki sebuah bagian penting dalam Informasi pelayanan publik yaitu bagian Pusat Pelayanan Terpadu Satu Pintu yaitu sebuah bagian yang mengumpulkan segala bentuk Informasi yang berhubungan dengan kegiatan dalam bidang Informasi surat di Kantor Wilayah Kementerian Agama Provinsi Riau. Pegawai PTSP akan mengumpulkan dan mengolah data surat masuk dan surat keluardalam pembuatan surat menyurat masih menggunakan cara yang konvensional. Berdasarkan permasalahan yang ada, maka akan dibangun sebuah sistem Informasi yang dapat membantu para pegawai bagian PTSP di Kantor Wilayah Kementerian Agama Provinsi Riau. Berdasarkan hasil uji blackbox sistem ini berjalan dengan baik dan sesuai dengan yang diharapkan. Berdasarkan pengujian User Acceptance Test (UAT) yang telah dilakukan oleh pengguna sistem di Kantor Wilayah Kementerian Agama Provinsi Riau mengatakan secara keseluruhan sistem ini mudah dipahami dan sesuai dengan apa yang diharapkan.

Kata Kunci : $\quad$ Kantor Wilayah Kementerian Agama Provinsi Riau, Sistem Informasi Administrasi Surat Menyurat 


\section{PENDAHULUAN}

Teknologi dan Informasi sangat berperan dalam dunia kerja maupun dalam kehidupan sehari-hari. Dengan teknologi penyelesaian suatu permasalahan bisa dilakukan lebih cepat jika dibanding dengan cara yang konvensional, contohnya dalam sebuah instansi pemerintahan membutuhkan komputer untuk mencapai suatu pengelolaan data yang baik dan terstruktur sehingga memperoleh Informasi yang berguna(Sutabri, 2014).

Teknologi komputer juga berpengaruh dalam bidang pemerintahan, penggunaan komputer sangat diperlukan untuk mengelola suatu administrasi/jasa pendidikan misal perguruan tinggi memerlukan informasi yang cepat, akurat dan tepat. Perkembangan dan pemanfaatan teknologi informasi berbasis web saat ini semakin meluas di segala bidang, yaitu untuk mempermudah kinerja dalam kegiatan sehari-hari termasuk dalam pengolahan data surat masuk dan surat keluar (Ramadhani et al., 2018). Dengan kecepatan pengolahan data serta penyimpanan informasi dapat memberikan kemudahan bagi setiap instansi, karena seluruh data ataupun informasi yang harus diolah tidak memungkinkan untuk dilakukan secara manual (Siti, 2015). Pengolahan data dengan jumlah besar memerlukan alat bantu dengan tingkat kecepatan perhitungan dan penyampaian data yang tinggi seperti perangkat keras (hardware) maupun perangkat lunak (software)(Saide et al., 2019). Dengan keunggulan komputer maupun web dalam pembentukan surat menyurat akan memproses data secara lebih efektif, produktif, dan efisien.

Kantor Wilayah Kementerian Agama Provinsi Riau adalah Kementerian yang membidangi urusan keagamaan. Kantor Wilayah Kementerian Agama Provinsi Riau juga memiliki bagian penting dalam Informasi pelayanan publik yaitu bagian Pusat Pelayanan Terpadu Satu Pintu. Berdasarkan hasil wawancara di dengan kepala Sub Bagian Organisasi Tata Laksana dan Kepegawaian Bapak Drs H. Efriom Efni, M.Ag, dalam pembuatan surat menyurat masih menggunakan cara yang konvesional yang mana wawancara dilakukan pada tanggal 31 oktober 2019 dikantor kemenag provinsi riau. Proses meliputi: cetak lembar disposisi surat masuk, pencatatan surat keluar ke dalam buku disposisi, pencarian dokumen surat dan lain sebagainya(Arismanto \& Rahmadhani, 2019). Proses konvensional ini tentunya memakan waktu sehingga menjadi salah satu faktor lamanya proses pelayanan. Disposisi surat masuk dan keluar yang harus ditandatangani kepala bagian secara manual juga menjadi kendala serta masalah lainnya menyangkut kelancaran pelayanan.

Sistem informasi surat menyurat dapat memberikan proses yang baik dan kelancaran dalam proses pelayanan surat menyurat. Berdasarkan permasalahan penulis bermaksud membangun sebuah sistem Informasi yang dapat membantu bagian PTSP di Kantor Wilayah Kementerian Agama Provinsi Riau dalam mengelola surat menyurat(Ridwan, Muhammad \& Ramadhani, 2017). Sistem yang akan dibuat adalah Sistem Informasi Administrasi Surat Menyurat. Penulis berharap dengan adanya sistem ini dapat mengurangi kendala yang ada dan meningkatkan kinerja para pegawai.

\section{Pengertian sistem informasi}

Sistem adalah kumpulan elemenelemen yang berinteraksi untuk mencapai suatu tujuan tertentu. Elemen-elemen itu tidak berdiri sendiri, tetapi saling berhubungan membentuk suatu kesatuan sehingga tujuan atau sasaran sistem dapat tercapai (Jogiyanto, 2017).

Adapun elemen-elemen yang membentuk sebuah sistem antara lain sebagai berikut:

1. Pencapaian tujuan, setiap sistem memiliki tujuan (goal) entah hanya satu atau mungkin banyak. Tujuan inilah 
yang menjadi pemotivasi yang mengarahkan sistem untuk terus menerus dalam usaha mencapai tujuan.

2. Masukan (Input) adalah segala sesuatu yang akan masuk ke dalam sistem dan selanjutnya menjadi bahan untuk diproses. Pada sistem Informasi, masukan dapat berupa data transaksi dan data non-transaksi (misalnya surat pemberitahuan) serta instruksi.

3. Proses, proses merupakan bagian yang melakukan perubahan atau transformasi dari masukan menjadi keluaran yang berguna. Pada sistem Informasi proses dapat berupa suatu tindakan yang bermacam-macam. Seperti meringkas data, melakukan perhitungan serta mengurutkan data.

4. Keluaran (Output), keluaran merupakan hasil dari pemrosesan. Pada sistem Informasi, keluaran bisa berupa suatu Informasi, saran, cetakan laporan dan sebagainya.

5. Mekanisme pengendalian dan umpan balik, mekanisme pengendalian (controlmechanism), diwujudkan dengan menggunakan umpan balik (feedback), yang mencuplikan keluaran. Umpan balik digunakan untuk mengendalikan baik masukan maupun proses. Tujuannya adalah untuk mengatur agar sistem berjalan sesuai dengan tujuan.

6. Batas, yang disebut batas (boundary) sistem adalah pemisah antara sistem dan daerah di luar sistem (lingkungan). Batas sistem menentukan konfigurasi, ruang lingkup, atau kemampuan sistem. Batas sebuah sistem dapat dikurangi atau dimodifikasi sehingga akan mengubah perilaku sistem.

7. Lingkungan adalah segala sesuatu yang berada di luar sistem. Lingkungan bisa berpengaruh terhadap operasi sistem dalam arti bisa menguntungkan atau merugikan sistem itu sendiri.

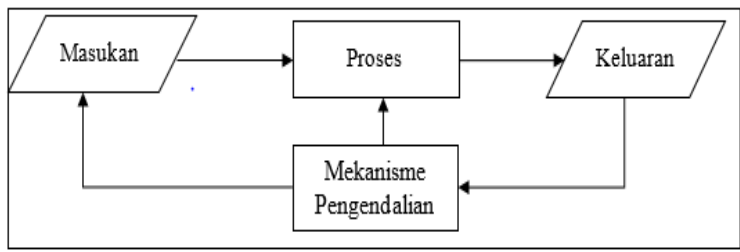

\section{Gambar 1 Proses Transformasi Sistem Dengan Mekanisme Pengendalian}

Informasi adalah rangkaian data yang mempunyai sifat sementara, tergantung dengan waktu, mampu memberikan kejutan atau surprisepada penerimanya. Identitas dan lamanya kejutan dari Informasi, disebut nilai Informasi (Nazwita, Siti, 2017). Informasi yang tidak mempunyai nilai, biasanya karena rangkaian data yang tidak lengkap atau kadaluwarsa (Romney \& Steinbart, 2015)

Selain itu ada juga pendapat para ahli mengenai pengertian Informasi menurut Davis dalam buku (Kadir, 2014)Informasi adalah data yang telah di olah menjadi sebuah bentuk yang berarti bagi penerimanya dan bermanfaat dalam pengambilan keputusan saat ini atau saat mendatang.

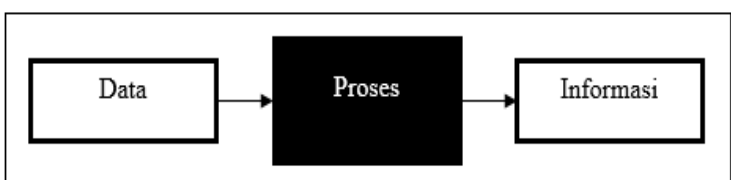

Gambar 2 Proses Transformasi Data Menjadi Informasi

Informasi yang berkualitas memiliki 3 kriteria (Kusrini \& Koniyo, 2007), yaitu:

1. Akurat (accurate)

Informasi harus bebas dari kesalahan, tidak bias ataupun menyesatkan. Akurat juga berarti bahwa Informasi itu harus dapat dengan jelas mencerminkan maksudnya.

2. Tepat pada waktunya (timelines) Informasi yang datang pada penerima tidak boleh terlambat. Di dalam pengambilan keputusan, Informasi yang sudah usang tidak lagi bernilai. Bila Informasi datang terlambat sehingga pengambilan keputusan 
terlambat dilakukan, hal itu dapat berakibat fatal bagi perusahaan.

3. Relevan (relevance)

Informasi yang disampaikan harus mempunyai keterkaitan dengan masalah yang akan dibahas dengan Informasi tersebut. Informasi harus bermanfaat bagi pemakainya. Di samping karakteristik, nilai Informasi juga ikut menentukan kualitasnya. Nilai Informasi (valueofinformation) ditentukan oleh dua hal, yaitu manfaat dan biaya untuk mendapatkannya. Suatu Informasi dikatakan bernilai bila manfaatnya lebih besar dibanding biaya untuk mendapatkannya.

Sistem Informasi adalah suatu sistem di dalam suatu organisasi yang mempertemukan kebutuhan pengolahan transaksi harian, mendukung operasi, bersifat manajerial dan kegiatan strategi dari suatu organisasi dan menyediakan pihak luar tertentu dengan laporan-laporan yang diperlukan

Fungsi sistem Informasi menurut Anggraeni dan Irvani (Anggraeni \& Irviani, 2017) adalah sebagai berikut:

1. Untuk meningkatkan aksebilitas data yang ada secara efektif dan efisien kepada pengguna, tanpa dengan perantara sistem Informasi.

2. Memperbaiki produktivitas aplikasi pengembangan dan pemeliharaan sistem.

3. Menjamin tersedianya kualitas dan keterampilan dalam memanfaatkan sistem Informasi secara kritis.

4. Mengidentifikasi kebutuhan mengenai keterampilan pendukung sistem Informasi.

5. Mengantisipasi dan memahami akan konsekuensi ekonomi.

6. Menetapkan investasi yang akan diarahkan pada sistem Informasi.

7. Mengembangkan proses perencanaan yang efektif.

\section{Komponen sistem informasi}

Komponen-komponen dari sistem Informasi (Anggraeni \& Irviani, 2017) adalah sebagai berikut:

1. Komponen Input, adalah data yang masuk ke dalam sistem Informasi.

2. Komponen model, adalah kombinasi prosedur, logika, dan model matematika yang memproses data yang tersimpan di basis data dengan cara yang sudah ditentukan untuk menghasilkan keluaran yang diinginkan.

3. Komponen Output, adalah hasil Informasi yang berkualitas dan dokumentasi yang berguna untuk semua tingkatan manajemen serta semua pemakai sistem.

4. Komponen teknologi, adalah alat dalam sistem Informasi, teknologi digunakan dalam menerima Input, menjalankan model, menyimpan dan mengakses data, menghasilkan dan mengirimkan Output, dan memantau pengendalian sistem.

5. Komponen basis data, adalah kumpulan data yang saling berhubungan yang tersimpan di dalam komputer dengan menggunakan softwaredatabase.

6. Komponen kontrol, adalah komponen yang mengendalikan gangguan terhadap sistem Informasi

\section{Sistem informasi surat menyurat}

Sistem Informasi Surat Menyurat adalah sebuah aplikasi yang diperuntukan untuk mengelola administrasi surat masuk maupun surat keluar. Dengan adannya aplikasi ini surat - surat yang sudah lama dan usang dapat dikelola lebih baik lagi (Bayu Hananto, Catur Nugrahaeni Puspita Dewi, 2017).

\section{Pengertian Surat Masuk}

Surat masuk adalah surat yang diterima dari perusahaan atau instansi lain kepada pihak yang bersangkutan. Surat masuk merupakan saran komunikasi tertulis yang diterima dari instansi atau perorangan. Dapat pula diartikan, surat 
masuk adalah semua jenis surat yang diterima instansi lain maupun perorangan, baik yang diterima melalui pos maupun yang diterima dari kurir dengan mempergunakan buku pengiriman.

Pengendalian dan pengurusan surat masuk dalam instansi dapat digolongkan menurut penggolongan jenis surat yaitu:

1. Surat penting

Semua surat yang mengemukakan semua masalah-masalah pokok yang mempengaruhi langsung ataupun tidak langsung, berhasil tidaknya pencapaian tujuan organisasi.

2. Surat rutin atau biasa

Surat yang tidak tergolong penting, surat-surat tersebut langsung di tindak lanjuti, relatif singkat dan tidak disimpan terlalu lama.

3. Surat rahasia

Surat yang harus disampaikan sesegera mungkin kepada pimpinan (orang yang bersangkutan) yang masih dalam keadaan tertutup, sehingga surat tersebut tidak boleh dibuka oleh penerima surat.

4. Surat pribadi

Surat yang disimpulkannya tercantum nama pribadi orang yang bersangkutan, walaupun disertai jabatan formalnya.

\section{Pengertian Surat Keluar}

Surat keluar yaitu surat yang dikirim dari pihak baik instansi, organisasi atau perusahaan yang berisi tentang suatu Informasi atau data baik itu perintah, pemberitahuan maupun Informasi lainnya. Surat keluar adalah surat yang sudah lengkap (bertanggal, bernomor, berstempel dan telah ditandatangani oleh pejabat yang berwenang yang dibuat oleh suatu instansi atau lembaga lain).

\section{Prosedur Penanganan Surat Masuk}

Pengurusan surat-surat mempunyai pengaruh yang penting terhadap pekerjaan kantor, karena itu perlu membuka suratsurat dan memerlukan pencatatan ataupun penyimpanan surat sebelum pekerjaan kantor dimulai. Surat masuk adalah suratsurat yang diterima oleh suatu organisasi, baik dari organisasi lain atau perseorangan

Surat yang masuk pada prinsipnya diterima melalui loket penerimaan surat yang telah disiapkan, atau langsung dikirim kepada sekretariat pimpinan atau diambil sendiri dari kotak pos. Setelah surat diterima oleh bagian penerima surat, selanjutnya surat tersebut diadakan pengolahan surat. Menurut Herijanto (Herijanto,1994).prosedur penanganan surat masuk pada suatu organisasi secara umum meliputi aktivitas-aktivitas sebagai berikut :

1. Penerimaan Surat

a. Mengumpulkan surat masuk yang diterima

b. Meneliti ketepatan alamat surat

2. Penyortiran Surat

a. Memisahkan surat ke dalam surat dinas (biasa, penting, atau rahasia) maupun surat pribadi

b. Menyortir berdasarkan tujuannya

3. Pembukaan Surat

a. Membaca surat dinas (biasa, penting atau rahasia)

b. Memeriksa lampiran-lampiran

c. Membubuhkan sampel agenda

4. Penggandaan surat masuk

a. Mencatat surat ke dalam buku agenda surat masuk

5. Pengklasifikasian surat

a. Mengumpulkan berdasarkan jenis dan tingkat kepentingan surat

6. Pendistribusian surat

a. Menyampaikan surat-surat ke alamat yang dituju

b. Mengklasifikasikan surat-surat kepada pimpinan dengan menyusun dari yang paling penting sampai kurang penting.

c. Menentukan pejabat mana yang harus menangani surat, dengan menyertakan disposisi (untuk mencatat instruksi pimpinan). 


\section{Prosedur Penanganan Surat Keluar}

Surat keluar adalah surat yang sudah lengkap (bertanggal, bernomor, berstempel dan telah ditandatangani oleh pejabat yang berwenang) yang dibuat oleh suatu instansi, kantor atau lembaga untuk ditunjukkan atau dikirim kepada instansi, kantor atau lembaga lain. Surat keluar merupakan surat yang harus diselesaikan oleh pihak kantor untuk intern maupun ekstern (Jetiskidul, 2014)

Prosedur atau tahapan-tahapan dalam pengelolaan surat keluar dapat dilihat pada gambar 4.3:

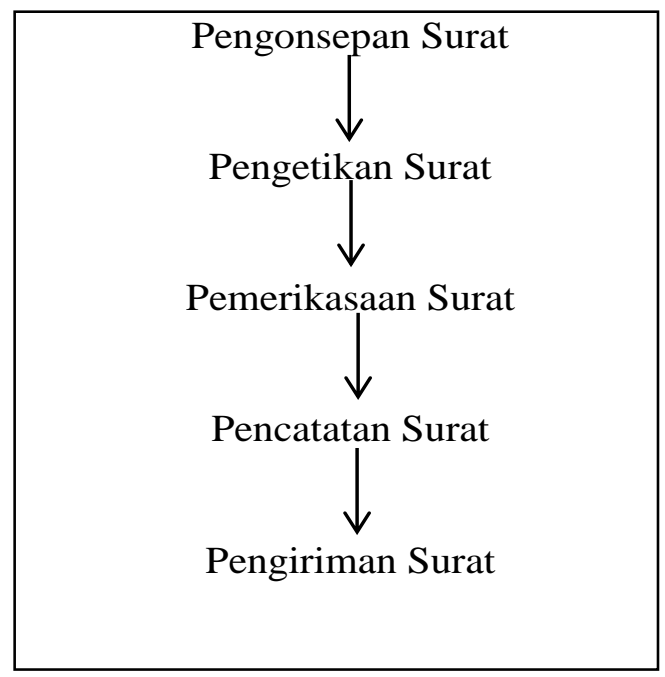

Gambar 3 Prosedur Penanganan Surat Keluar

Keterangan :

1. Pengonsepan yaitu pembuatan rancangan surat yang dilakukan oleh pimpinan perusahaan sebelum diberikan kepada sekretaris

2. Pengetikan, setelah konsep surat selesai dan diserahkan kepada sekretaris maka surat siap untuk diketik sesuai dengan yang telah ditentukan.

3. Pemeriksaan, pimpinan kembali memeriksa surat yang telah diketik apabila ada kekurangan dan telah benar penulisannya.

4. Pencatatan, setelah diperiksa surat tersebut ditulis pada buku agenda sesuaidengan nomor surat yang telah dikeluarkan.

\section{ClassDiagram}

Diagram kelas atau class Diagram menggambarkan keadaan (attribute/property) dalam suatu sistem. Sekaligus menawarkan layanan untuk memanipulasi keadaan tersebut (metode/fungsi) Invalid source specified.

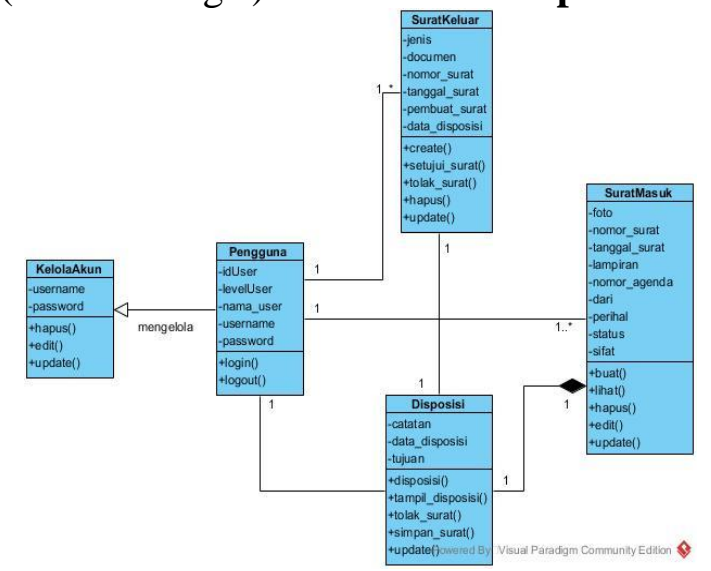

Gambar 4 ClassDiagram Sistem Informasi Administrasi Surat

Pada gambar diatas adalah class diagram dari sistem informasi administrasi surat. Class diagram diatas adalah gambaran dari database sistem informasi administrasi surat yaitu ada tabel kelolaAkun yang memiliki atribut username dan password. Tabel penggunaa memiliki atribut idUser, levelUser, nama_user, username dan password. Tabel disposisi memiliki atribut catatan, data_disposisi dan tujuan. Tabel suratmasuk memiliki atribut foto, nomor_Surat, tanggal_Surat, lampiran, nomor_agenda, dari, perhila, status, dan sifat. Tabel suratkeluar jenis, dokumen, nomor_surat, tanggal_surat, pembuatan_surat dan data_disposisi.

\section{Rancangan Antar muka}

Antar muka adalah salah satu layanan yang disediakan sebagai sarana interaksi antara pengguna dengan sistem, menekankan dalam hal tampilan yang mudah dimengerti. Berikut adalah perancangan Antar muka pada Sistem Informasi Administrasi Surat Menyurat Kantor Wilayah Kementerian Agama Provinsi Riau

1. Perancangan antar muka login pengguna 


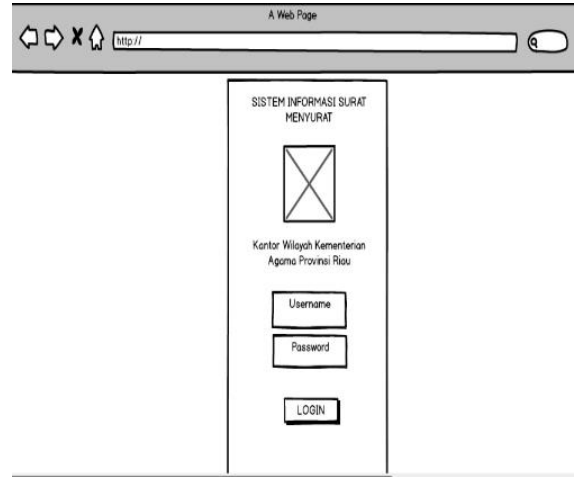

Gambar 5 Perancangan Antar muka Login

2. Perancangan antar muka dashboard pengguna

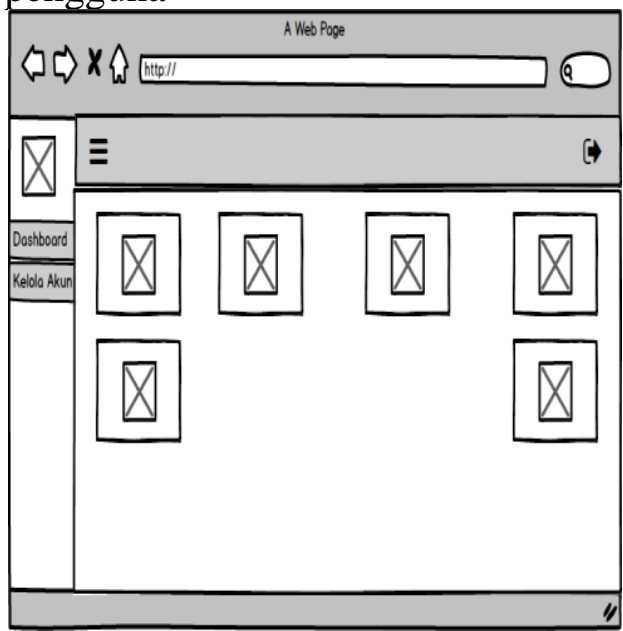

Gambar 6 Perancangan antar muka Dashboard Pengguna

5. Perancangan antar muka kelola akun

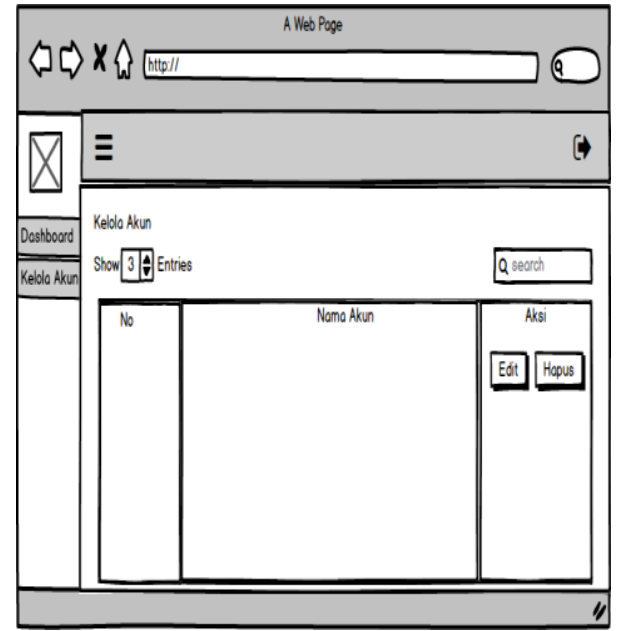

Gambar 7 Perancangan antar muka Kelola Akun

6. Perancangan antar muka edit data akun

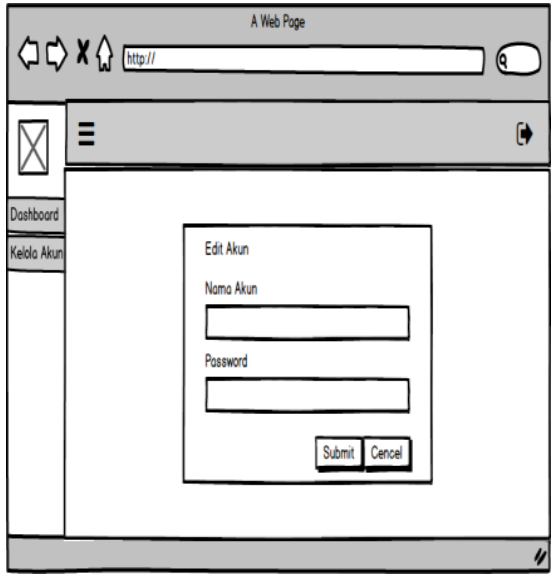

Gambar 8 Perancangan antar muka Edit Data Akun

7. Perancangan antar muka halaman surat masuk

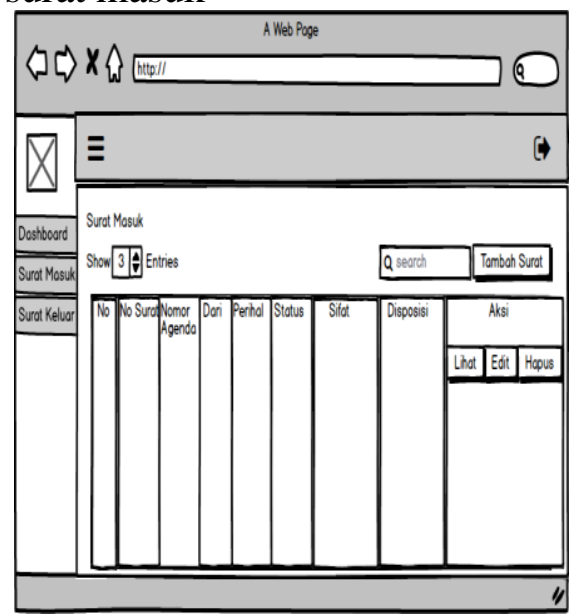

Gambar 9 Perancangan antar muka Halaman Surat Masuk

8. Perancangan antar muka form tambah surat masuk

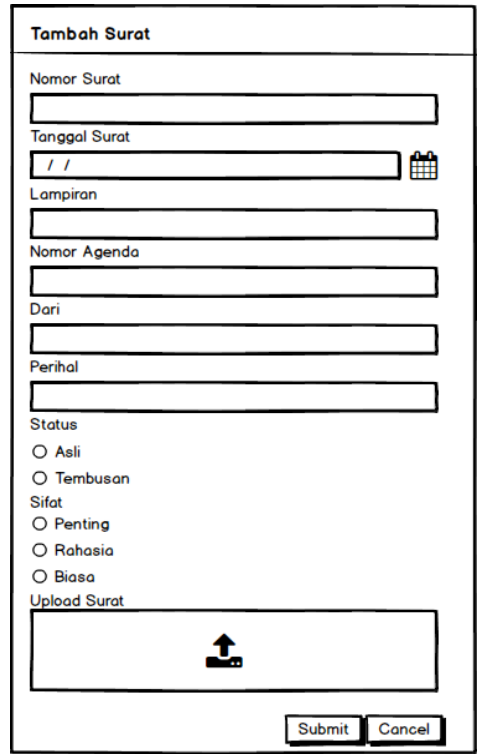




\section{Gambar 10 Perancangan Form Tambah Data Surat Masuk}

9. Perancangan antar muka edit data surat masuk

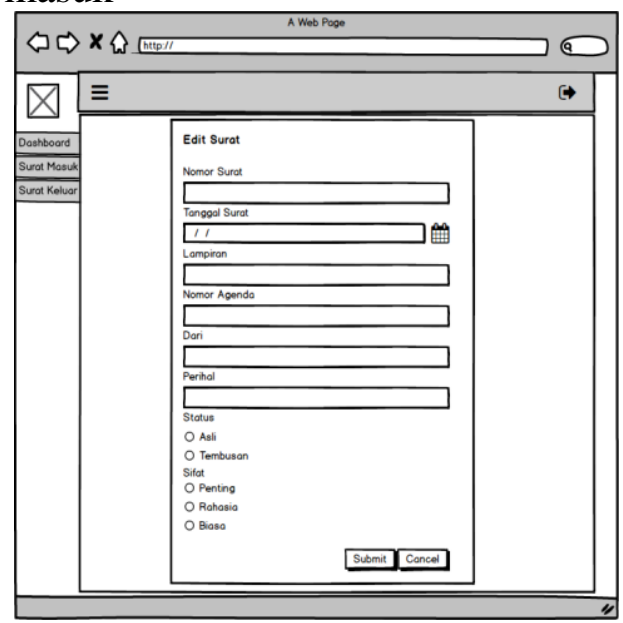

Gambar 11 Perancangan antar muka Edit Data Surat Masuk

10. Perancangan antar muka lihat surat masuk

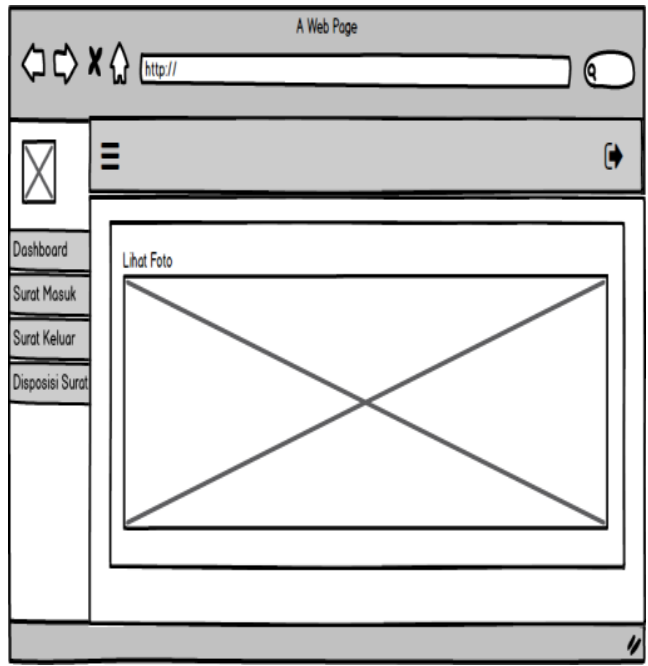

Gambar 12 Perancangan antar muka Lihat Surat Masuk
11. Perancangan antar muka form disposisi surat masuk

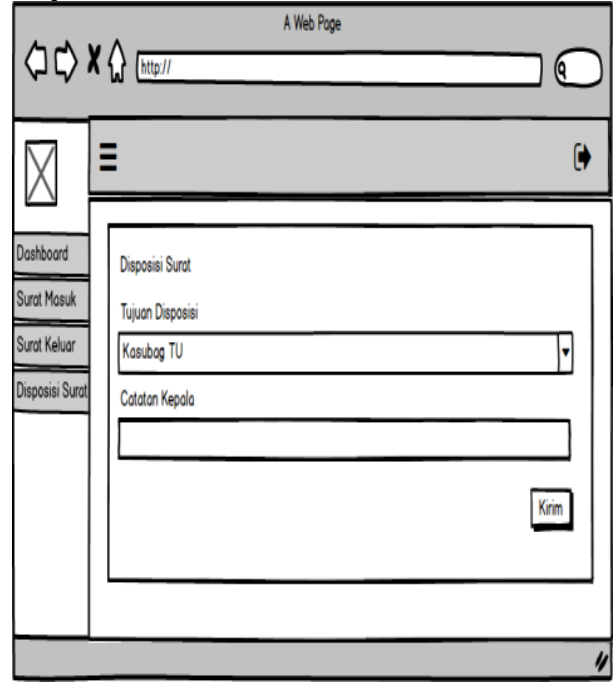

Gambar 13 Perancangan antar muka Form Disposisi Surat Masuk

12. Perancangan antar muka halaman surat keluar

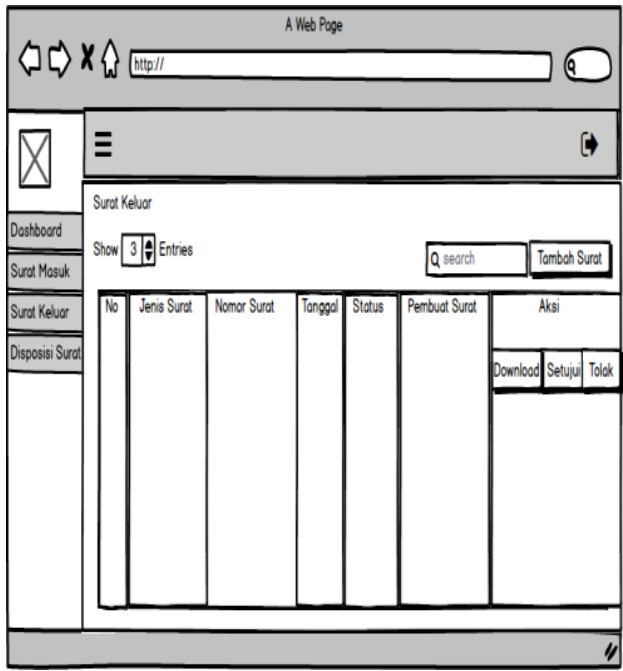

Gambar 14 Perancangan antar muka Halaman Surat Keluar 
13. Perancangan antar muka form tambah surat keluar

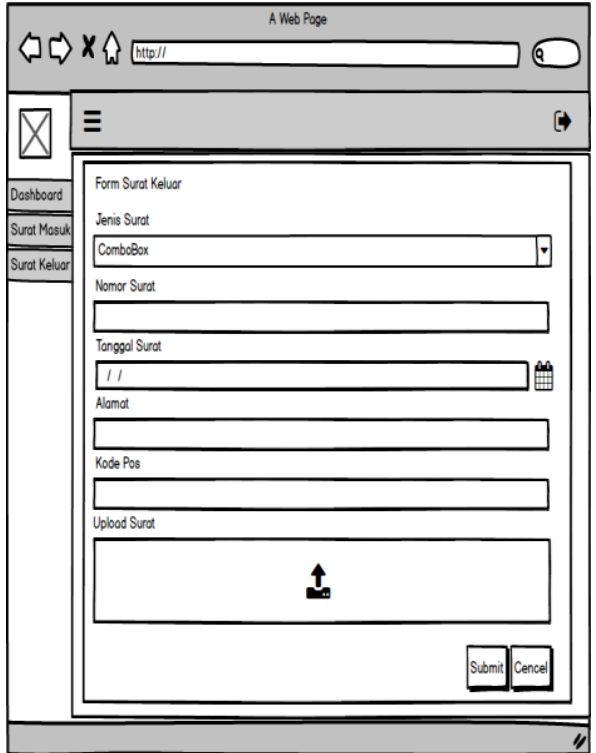

Gambar 15 Perancangan antar muka Form Tambah Surat Keluar

14. Perancangan antar muka halaman disposisi surat

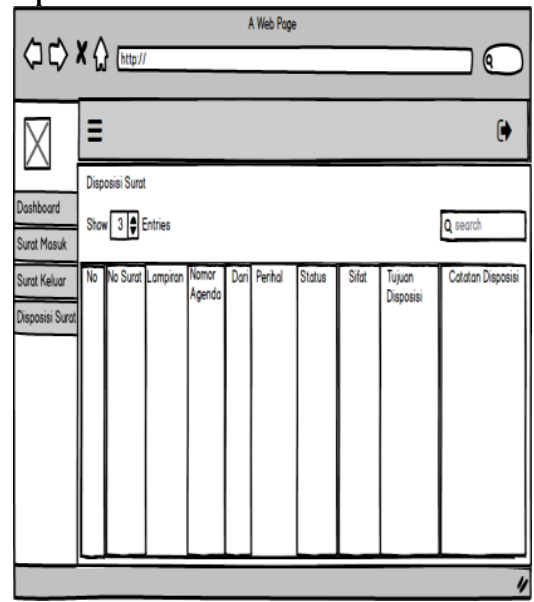

Gambar 16 Perancangan antar muka Halaman Disposisi Surat

\section{KESIMPULAN}

Berdasarkan pembahasan yang telah dilakukan pada bab-bab sebelumnya dalam kerja praktek ini dapat disimpulkan.

1. Sistem Infromasi Administrasi Surat Menyurat Di Kantor Wilayah Kementerian Agama Provinsi Riau telah selesai dibangun menggunakan sistem administrasi surat menyurat dengan web, dan diharapkan dapat mempermudah pegawai dalam pengelolaan administrasi surat masuk dan surat keluar yang ada di instansi terutama dibagian sub instansi Ortala sehingga tidak lagi melakukan administrasi surat menyurat dengan cara manual.

2. Berdasarkan hasil uji blackbox sistem ini berjalan dengan baik

3. Berdasarkan pengujian User Acceptance Test (UAT) yang telah dilakukan oleh pengguna sistem di Kantor Wilayah Kementerian Agama Provinsi Riau mengatakan "Sangat Baik "dengan Presentasenya yaitu $83 \%$, dan secara keseluruhan sistem ini mudah dipahami dan sesuai dengan apa yang diharapkan.

\section{UCAPAN TERIMAKASIH}

Terimakasih saya ucapkan kepada UIN Sultan Syarif Kasim Riau dan Kantor Wilayah Kementerian Agama Provinsi Riau yang memberikan peluang dalam melakukan penelitian ini.

\section{DAFTAR PUSTAKA}

Anggraeni, E. Y., \& Irviani, R. (2017).

Pengantar Sistem Informasi. Yogyakarta: CV. ANDI OFFSET.

Jogiyanto, H. (2017). Anilisis \& Desain Sistem Informasi . Yogyakarta: CV. ANDI OFFSET.

Kadir, A. (2014). Pengenalan Sistem Informasi. Yogyakarta: CV. ANDI OFFSET.

Munawar. (2005). Pemodelan Visual Dengan UML. Yogyakarta: Graha Ilmu.

Sutabri, T. (2014). Pengantar Teknologi Informasi. Yogyakarta: CV. ANDI OFFSET. 
Akil, I. (2016). Rekayasa Perangkat Lunak Dengan Model Unified Process Studi Kasus: Sistem Informasi Journal. Jurnal Pilar Nusa Mandiri, XII(1), 1-11.

Akil, I. (2016). Rekayasa Perangkat Lunak Dengan Model Unified Process Studi Kasus: Sistem Informasi Journal. Jurnal Pilar Nusa Mandiri, XII(1), 1-11.

Firman, A., Wowor, H. F., \& Najoan, X. (2016). Sistem Informasi Perpustakaan Online Berbasis Web. Jurnal Teknik Elektro dan Komputer, 5(2), 29-36.

Hananto, B., Dewi, C. N., \& Raafiudin, R. (2017). Pelatihan Sistem Informasi Kependudukan dan Dasawisma Berbasis Web Dengan Menggunakan Framework Codeigniter Pada Tingkat RT. Jurnal Sains Teknologi, 7(2), 280285.

Hendini, A. (2016). Pemodelan UML Sistem Informasi Monitoring Penjualan dan Stok Barang (Studi Kasus: Distro Zhezha Pontianak). Jurnal Khatulistiwa Informatika, IV(2), 41-51.

Mahdiana, D. (2016). Pengadaan Barang Dengan Metodologi Berorientasi Obyek: Studi Kasus PT. Liga Indonesia. Jurnal TELEMATIKA, $3(2), 36-43$.

Munthe, R., Santosa, P. I., \& Ferdiana, R. (2015). Usulan Metode Evaluasi User Acceptance Testing (UAT) dalam Pengembangan Perangkat Lunak. SENAPATI, 159-162.

Pohan, S. (2015). Pemodelan UML Untuk Menentukan Kelulusan Penerimaan Mahasiswa Baru Berbasis Web. Jurnal Ilmiah AMIK Labuhan Batu, 3(2), 41-51.
Pratama, I. W., \& Nurlela, I. (2018). Sistem Informasi Akuntansi Aset Tetap Kendaraan Pada CV Bumi Waras di Bandar Lampung. Jurnal Sistem Informasi Akuntansi, 1(1), 56-66.

Rahadi, N. W., \& Vikasari, C. (2020). Pengujian Software Aplikasi Perawatan Barang Miliki Negara Menggunakan Metode Black Box Testing Equivalence Partitions. Jurnal Infotekmesin, 11(01), 57-61.

Santoso, \& Nurmalina, R. (2017).

Perencanaan dan Pengembangan Aplikasi Absensi Mahasiswa Menggunakan Smart Card Guna Pengembangan Kampus Cerdas (Studi Kasus Politeknik Negeri Tanah Laut). Jurnal Integrasi, 9(1), 84-91.

Saputra, K. A., \& Famukhit, M. L. (2014). Perancangan Sistem Informasi Pengelolaan Surat Masuk dan Surat Keluar Pada MTs Guppi Jetiskidul. Indonesian Journal on Networking and Security, 3(4), 59-62.

WIjaya, T. (2018). Penerapan Metode Scrum dan Virtual Private Network Dalam Perancangan Sistem Ordersale. Jurnal Sistem Informasi STMIK Pontianak, 11(1), 115-125.

Arismanto, B., \& Rahmadhani, S. (2019). Pengembangan Sistem Penerimaan Mahasiswa Baru pada STIES Imam Asy Syafii Pekanbaru. Jurnal IntraTech, 3(1), 57-72.

Nazwita, Siti, R. (2017). Analisis Sistem Keamanan Web Server Dan Database Server Menggunakan Suricata. Seminar Nasional Teknologi Informasi, Komunikasi Dan Industri (SNTIKI) 9, 308-317.

Ramadhani, S., Saide, S., \& Indrajit, R. E. (2018). Improving creativity of 
graphic design for deaf students using contextual teaching learning method (CTL). ACM International

Conference Proceeding Series, 136140.

https://doi.org/10.1145/3206098.3206 128

Ridwan, Muhammad, M., \& Ramadhani, S. (2017). Rancangan Sistem Informasi Manajemen Aset di PT . Sentral Tukang Indonesia. Jurnal CoreIT, 3(2), 47-53.

Saide, S., Indrajit, R. E., Trialih, R., Ramadhani, S., \& Najamuddin, N. (2019). A theoretical and empirical validation of information technology and path-goal leadership on knowledge creation in university:
Leaders support and social media trend. Journal of Science and Technology Policy Management, 10(3), 551-568.

https://doi.org/10.1108/JSTPM-062018-0067

Siti, R. (2015). Sistem Pencegahan Plagiarisme Tugas Akhir Menggunakan Algoritma Rabin-Karp (Studi Kasus: Sekolah Tinggi Teknik Payakumbuh). Jurnal Teknologi Informasi \& Komunikasi Digital Zone, 6(1), 44-52. 